ら炭素，ケイ素の吸収効果が推察される。

（3）鉄含有量少量試料に生ずる強調効果面熱鋼 試料注他鋼種に比し，モリブデンの補正をおこなつても 高值宗示。実験に使用した標準試料の鉄は $90 \%$ 以上 に対し，耐熱鋼試料 NBS 1187，1184，1185 の鉄量注 $40 \%, 80 \%, 70 \%$ である。P $K \alpha$ 線 $(6 \AA$ 丹 $)$ 質量吸収 係数は P： 245 に対し Fe：1400であるため, 耐熱鋼試 料は見かけ上強調効果があらわれていると推察される。

\section{4 検量線と分析誤差}

検量線はモリブデン, 鉄, 炭素, ケイ素などの共存元 素の影響军考虑して作成した. Table 4 に示すように炭 素鋼一低合金鋼, 銑鋳鉄および全鋼種共通検量線別に分 析誤差を検討したもので，銑鋳鉄試料はケイ素，炭素が 未補正のため，炭素鋼一低合金鋼試料に比し誤差が大で あり, 全鋼種共通検量線では本法は旧法に比し分析精度 が 2 3 倍向上した。ささらに定量限界について, 旧法で は $0.010 \%$ であつたものが，本法では $0.0015 \%$ となり， 1 桁向上した. また本法では $0.5 \%$ のモリブデンに対し リンの定量值に $0.005 \%$ の正誤差を与えたので，モリブ デン $0.5 \%$ 以上の試料に詨し, リンの定量值に補正を打 こなつた.

\section{5 分析感度向上に対する知見}

䖝光 $\mathrm{X}$ 線分析の分析感度向上には, $\mathrm{X}$ 線管球励起条 件・スリット巾・分光結晶および検知器の選定が必要で
あり，その要因として測定線と近接線との分離と線強度 の向上が考えられる. 近接線の分離はスリット巾の狭 いもの, 分光結晶の分散度の大きい種類の選定が常法で あるが, Table 2 に示すように管球の選定により妨害元 素の強度を減じることも可能と考えられる。 また測定線 の強度の向上ほ適性波長域の検出器を選ぶのは当然で あるが, 分光結晶の分散度の小さい種類, 適性波長域に 相応した管球，拉よび Fig. 2 に示すように管電流をで きるだけ大きくとる励起条件を選ぶことが考光られる。

\section{4. 結 論}

クロ ム管球，分光結晶 PET 它使用乙て溃光 X線分析 による鉄鋼中のリンの定量をおこなつた結果, 定量限 界 $0.0015 \%$, 平均誤差 $0.0029 \%$ ，標準偏差 $0.0034 \%$ であつた。これを先に報告したタングステン管球による 場合と比較すると $\mathrm{X}$ 線強度注約 6 倍, 分析精度は $2 \sim 3$ 倍, 定量限界は 1 桁向上したことがわかつた.

また共存元素の影響として, P $K \alpha$ 線に Mo $L_{l}$ 線の近 接. 炭素, ケイ素の吸収効果により銑鋳鉄試料は多少分 析精度が劣り，耐熱鋼試料怯鉄含有量が少ないため，見 かけ上の強調効果があらわれた. モリブデンの補正につ いては $0.5 \%$ 以上の試料について補正式を作り満足でき る結果がえられた。

長谷川：型板ガラスの透過光度測定について

\title{
型板ガラスの透過光度測定について
}

\author{
長 谷川泰*
}

（昭和 41 年 3 月 28 日受理）

Measurements on the Transmissive Luminous Intensity of Figured Glasses

\author{
Yasushi HASEGAWA* \\ * Research Raboratory of Central Glass Co., Ltd. \\ (2805, Imafuku-Nakadai, Kawagoe-shi, Saitama-ken, Japan)
}

Transmissive luminous intensity of commercial figured glass was measured by a goniophotometer and the light diffusion characteristics were discussed with the goniometrical curves obtained. It was found that curves depend on the pattern of figured glass. Numerical representation of curves by a statistical method was attempted, and the degree of diffusion was classified by the numerical values. 


\section{1. 緒}

\section{言}

市販されている型板ガラスの多くは，片面に連続模様 を製板時に，ローラーでつけたもので，他の面は模様の ないなめらかな面 (滑面) である. 型模様によるガラス 面の凹凸で透過光に拡散特性を与えると共に，透視性を 低下させている。

形板ガラスの透過光については，ウルブリヒト球を使 用し，全透過率を求めた例が知られている11. しかし透 過光の拡がり，拡散特性を数值的に示した例はないよう である，そこで本報告は型板ガラス面に垂直入射した平 行光束の, 透過側における光度分布を变角光度計で測定 し，その結果ををとめたものである。

\section{2. 試料, 測定装置ならび測定方法}

測定に供した型板ガラスは 23 種類で，いずれも片面 にの久模様のある市販品である。厚久により $2 \mathrm{~mm} の$

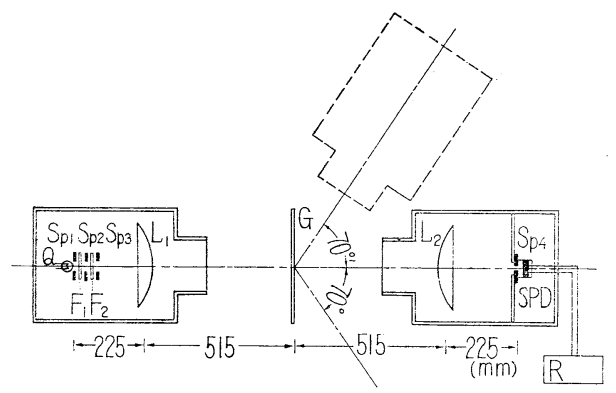

Fig. 1. Optical system of goniophotometer

Q : Light source, tungsten filament lamp. 6V, $5 \mathrm{~A}$.

$\mathrm{Sp}_{1}$ : Slit, $10 \mathrm{~mm} \phi$.

$\mathrm{Sp}_{2}$ : Slit, $20 \mathrm{~mm} \phi$.

$\mathrm{Sp}_{3}$ : Slit, $30 \mathrm{~mm} \phi$.

$\mathrm{F}_{1}$ : Interference filter. $\lambda_{\max }=544 \mathrm{~nm} ; T_{\max }=$ $35 \% ; \delta \lambda_{1 / 2}=10 \mathrm{~nm}$.

$\mathrm{F}_{2}$ : Neutral density filter. $\mathrm{T}-50,-25$, -12.5 (\%) optionally used.

$\mathrm{L}_{1}, \mathrm{~L}_{2}$ : Lens. $225 \mathrm{~mm} \phi, f=225 \mathrm{~mm}$.

G : Sample. $300 \times 300 \mathrm{~mm}$ large. Diameter of illuminated area: $150 \mathrm{~mm}$. Flat side of figured glass against incident luminous flux vertically set.

$\mathrm{Sp}_{4}$ : Slit, $2 \mathrm{~mm} \phi$.

SPD: Silicon photoelectronic diode. $20 \mathrm{~mm}$. (Hayakawa Electronic Co., Ltd.)

$\mathrm{R}$ : Recorder. EPR-2T (Towa Electronic Ltd.).

1) W. Eitel, M. Pirani und K. Sheel: GlastechTabellen. S. 502 505, 1931.
ものを薄型板 (うすかたいた， S で示す），4 mm のもの を厚型板（あつかたいた，Dで示す）に分けた。他に金 網入りの型板ガラスがこの中に含まれ，これの厚みは約 $7 \mathrm{~mm}$ ( $\mathrm{DD}$ の示す) である.また比較のため厚み $6 \mathrm{~mm}$ の磨板ガラスと，厚み $1.9 \mathrm{~mm}$ の摺板（すりいた）ガラ ス*をも測定に供した。試料の大きさは $30 \times 30 \mathrm{~cm}$ であ つた。

型板ガラスの光線透過特性を測定するに当つては型模 様に比較し充分な大きさの断面をもつ光束を使用する必 要がある.ここでは直径約 $150 \mathrm{~mm}$ の平行光束を使用 した.

つぎに型模様面を光束の入射側におくか，透過側にお゙ くかで, 透過光の光度も若干異なる. 此処では型板ガラ スの実用例にならって, 型模様面を透過側に, 滑面を大 射側においた。

また型模様に方向性のある場合に注，透過光の光度分 布も方向性を示したので, 測定時に出ける模様の方向之 受光器の回転面 (測角面) と方゙一致した場合を $(\mathrm{H})$, 直 角な場合を（V) で区別して示音ことにした，模様の配 列に方向性のない場合はこの必要心゙ないので一つの測定 例の名示した。

Fig. 1 に，測定に使用した試作変角光度計の光学系 の概略図を示吉．この光度計により，型板ガラス（30× $30 \mathrm{~cm}$ ) の滑面側に直径約 $150 \mathrm{~mm}$ の平行光束 (中心波 長 $545 \mathrm{~nm}$ とする緑色光）学垂直入射させ, 反対側の模 様面より射出される透過光束について, 光軸安中心に $5^{\circ}$ 間隔で $\pm 70^{\circ}$ の範囲にわたり光度分有安測定した。

光度分布は受光器スリットにより制約される受光光束 による照度測定から得られるもので，ここで示す光度は 相対的な值である。

円形光束の光源側, 受光側の開き角は約 $2^{\circ}$ である.

受光器の光電变換素子による電気的出力は記録計に接 続しデーターの整理を容易にした， 入射光度と記録計の 電圧 $(\mathrm{mV})$ 指示との関係注記録計の感度切換 $(5,10$, $25,100 \mathrm{mV}$ ) と, 受光器への入射光をフイルター（透過 率 $50,25,12.5 \%$ のD フイルター) で減光すること を併用して，1:103 の範囲で直線性を保持した。また角 度は受光器をモーターで定速回転 $\left(20^{\circ} / \mathrm{min}\right)$ させ，そ の変角度は記録紙上にマーカーで $5^{\circ}$ 毎にチエックした。 記録紙の送り速度は $60 \mathrm{~mm} / \mathrm{min}$ とした。

\section{3. 測定結果と考察}

\section{1 対変角透過光度分布曲線と型模様}

*一般にくもりガラスと呼ばれている普通板の片面空 研磨材で砂摺した板ガラスである。 
供試板ガラスの透過光に新ける搪散状態定対変角半対 数極座標表示で Fig. 2 5 亿示す. 同時に測定条件下に 透過側より撮影した型模梯の写真をもあわせて示す。

Fig. 2 飞示要ものは供試板ガラスのなかで，拡散の比 較的大きい例であり，Fig. 3 亿示亦ものはついで大きな ものである. Fig. 4 亿注方向性のある型模様とこ机他
の模様老組み合わせた例定示高. Fig. 5 亿注搪散の小さ な例定示すもので，その内 1 例は磨板ガラスである。な お比較のため測定した摺板ガラス汶昖散が大きく，Fig. 2 に示してある。

極座標による実測の対变角光度分布曲線が示すように 板ガラスの搪散光は光軸沉対し $\pm 20^{\circ}$ から $50^{\circ}$ ：以上の.

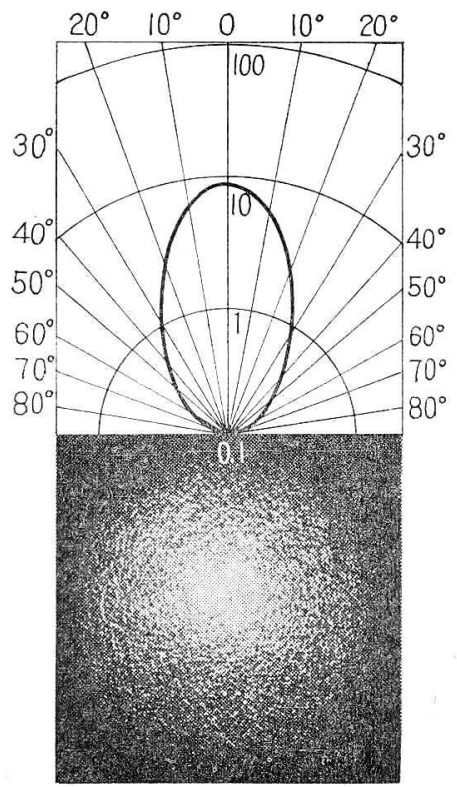

Fig. 2-1

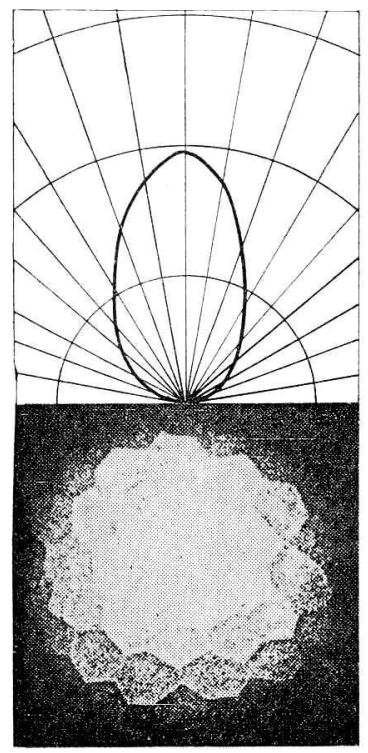

Fig. 2-4

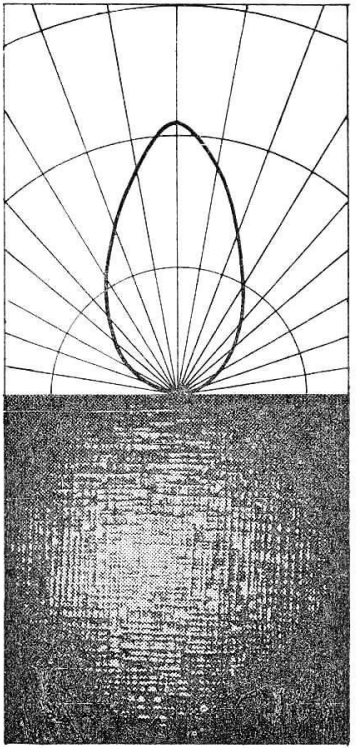

Fig. 2-2

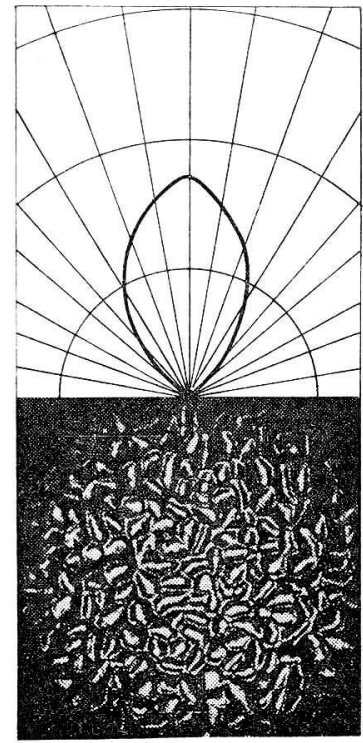

Fig. $2-5$

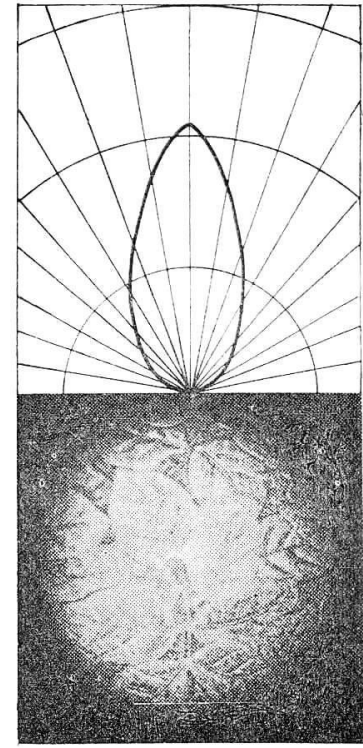

Fig. 2-3

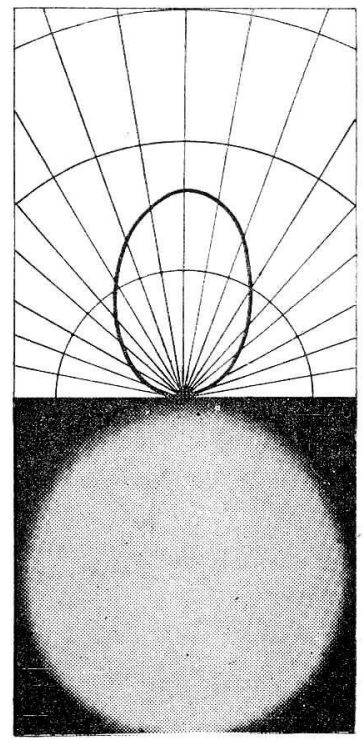

Fig. 2-6

Fig. 2. Goniometrical curves and patterns of glasses measured 


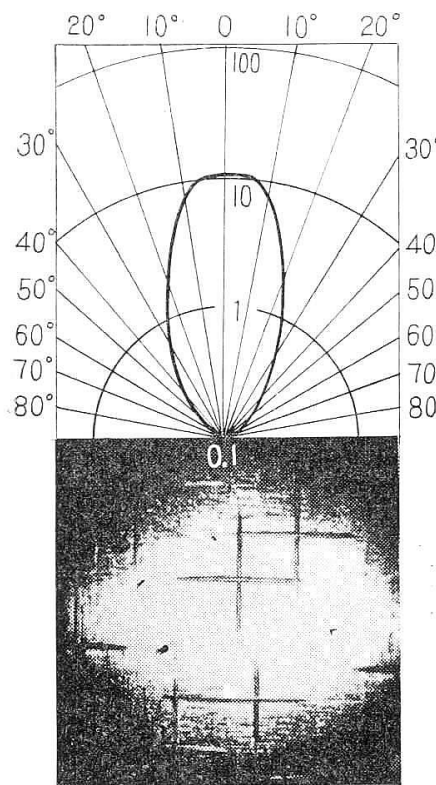

Fig. 3-1

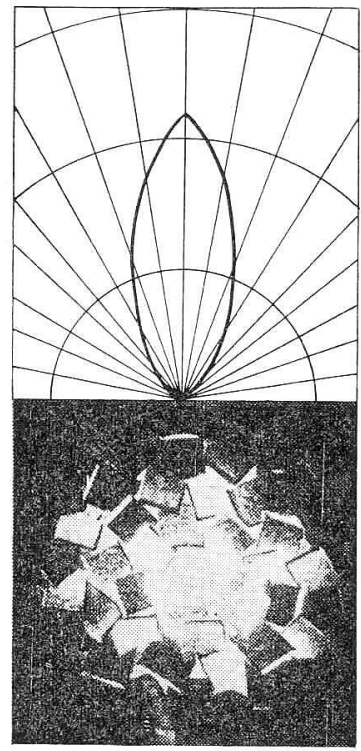

Fig. 3-4

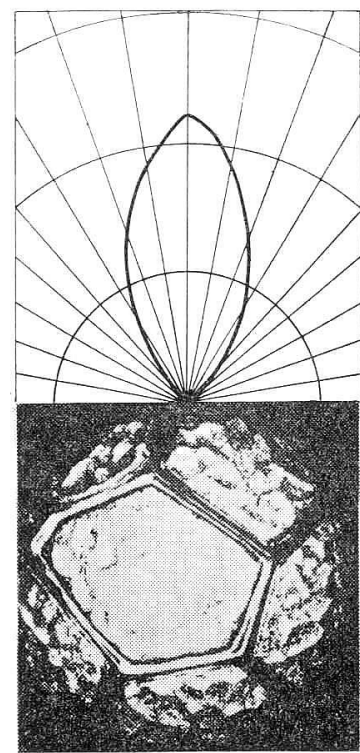

Fig. 3-2

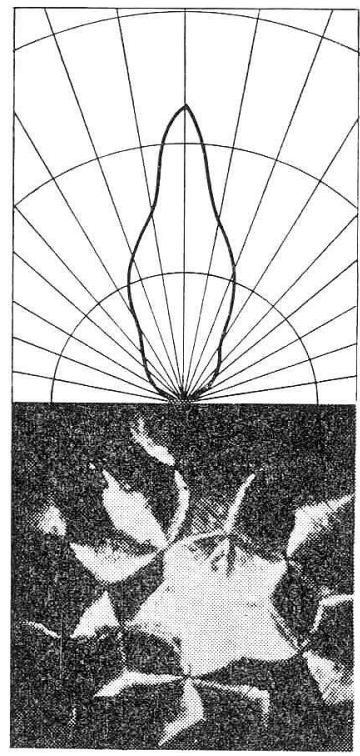

Fig. 3-5

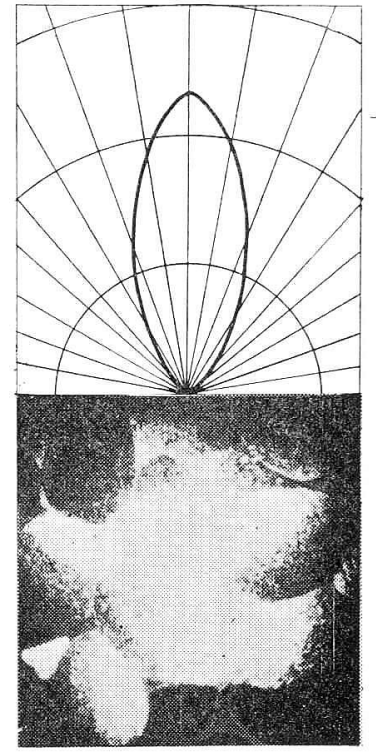

Fig. 3-3

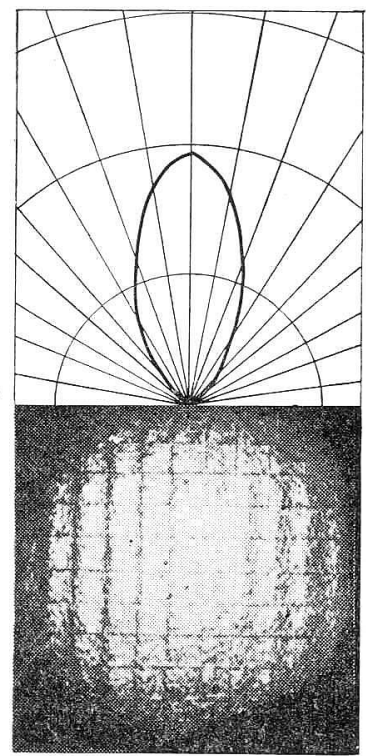

Fig. 3-6

Fig. 3. Goniometrical curves and patterns of glasses measured

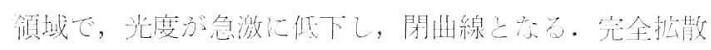

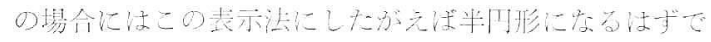
ある。

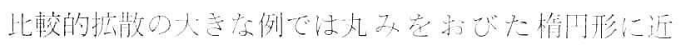
く，搪散吕小さくなるにしたがつて好みが少なくなり，
磨板ガラ大に胃られるように細居い，光軸近修の尖つた

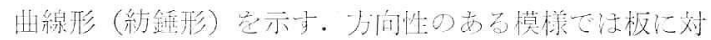

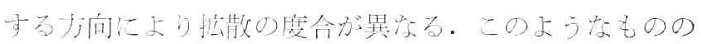
中经拉散の最も大きな例が見られる(試料No. 21(V)).

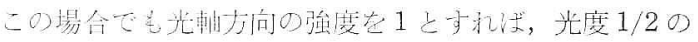




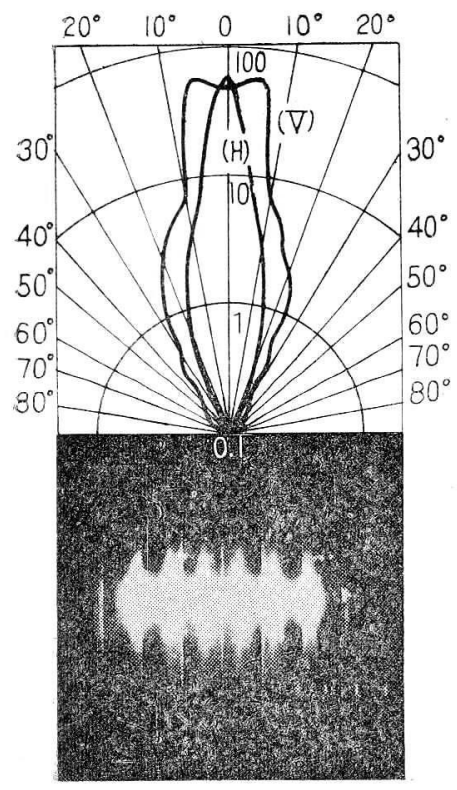

Fig. 4-1

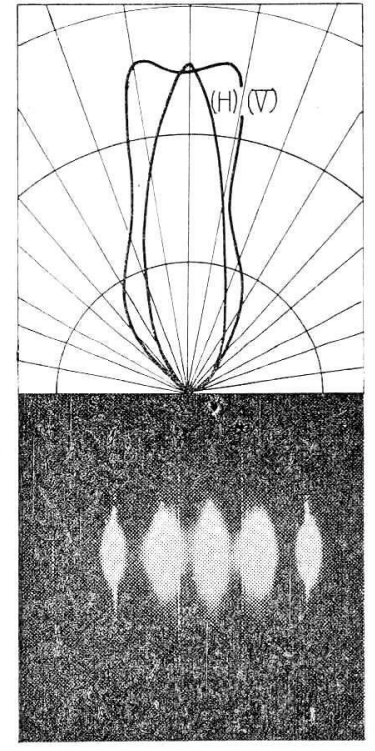

Fig. 4-2

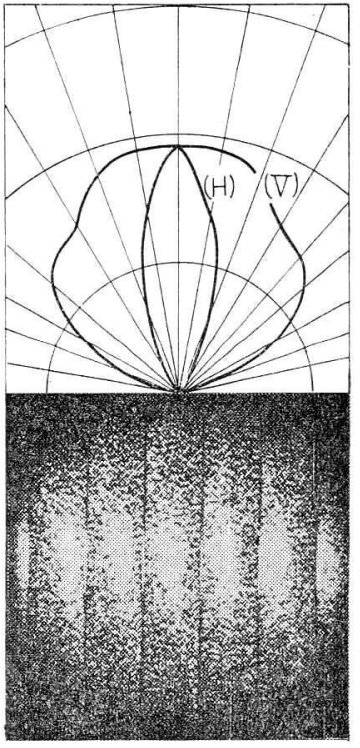

Fig. 4-3

Fig. 4. Goniometical curves and patterns of glasses measured

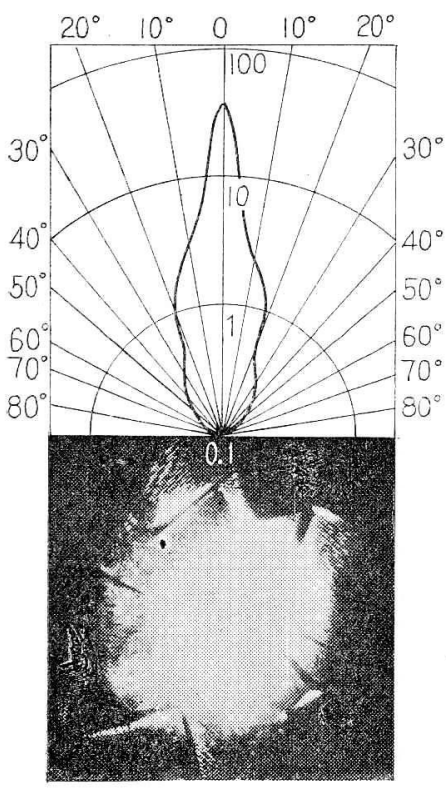

Fig. 5-1

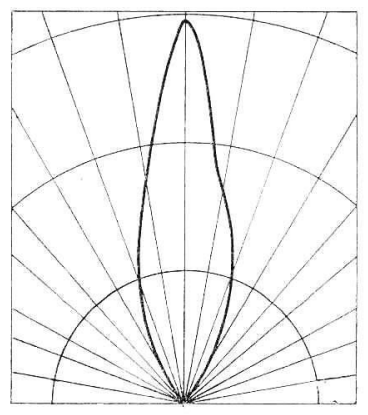

Fig. 5-2

Fig. 5. Goniometrical curves and pattern of glasses measured

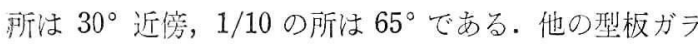
スでは $20^{\circ}$ 以内で $1 / 2,30 \sim 50^{\circ}$ で $1 / 10$ 以下に光度が 低下古る。
これら型板ガラスの透過光の光度分布曲線は密に型板 ガラスを使用する際, 壁の反射岩考えない室内空間にお ける光度分布を知る手がかりとならう。 
分布曲線中に泣部分的汇変形空生じているものがあ る・これらは 1 例を除いて, 型模様が大型の模㥞と小さ な模様の組み合わせか，方向性のある模様について見ら

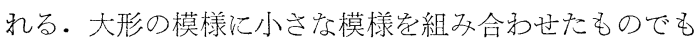
曲線が紡錘形をとり，局部的な変化を示さない場合もあ る。拡散特性が組み合わせるべき模様に左右されること は明らかなことである。

\section{2 分布曲線の解析と拡散度分の分類}

型板ガラスの透過光度分布を，ガラス面に垂直な光軸 方向を原点にとりその左右に打汀る变角度を横軸に，そ れに対子る光度を縦軸にとつて示すと，多くは鐘型の曲 線型となる・このような鐘型分布曲線は統計学的に正規 分布曲線と呼ばれる. Gauss の誤差曲線として知られる ものはこれの特殊例で標準正規分布曲線として区別され ている、今これらの曲線について, 変角度 $\left(x_{i}\right)$ が等間隔 であり, これに対する光度を $f(i)$, 測定点の総数を $n$ と すれば, 次式から求められる標準偏差 $(\sigma)$ やとがり $\left(\alpha_{4}\right)$ はそれぞれ変角度に対する透過光度の度数分布を示す重 要な尺度になる。

$$
\begin{aligned}
& \text { 標準偏差, } \quad \alpha=\sqrt{\frac{\sum_{i=1}^{n} f_{i}\left(x_{i}\right)^{2}}{\sum_{i=1}^{n} f_{i}}}, \\
& \text { とぶり, } \quad \alpha_{i}=\frac{\sum_{i=1}^{n} f_{i}\left(x_{i}\right)^{4}}{\sum_{h=1}^{n} f_{i} \sigma^{4}}
\end{aligned}
$$

標準偏差 $(\sigma)$ 法分布曲線のひろがりを，とがり $\left(\alpha_{4}\right)$ はとがり具合をとれぞれ数值的に示すことができる。 $\alpha_{4}$ は曲線自身がとがつた場合程大きくなり，頂部の低い末 広がりの場合には小さくなる。 きくなり， $\alpha_{4}$ とは逆の傾向を示主。

拡散特性を光度分布曲線のひろがりの大小から示す場 合，その数量表示には， $\sigma$ と $1 / \alpha_{4}$ で示すと都合がよい のでここではこれにしたがって示すことにする。

Table 1 《供試板ガラスの分布曲線について得られた 標準偏差ととがり逆数值を示す。

すでに述べたように試料により，その分布曲線が部分 的に变形し，簏密には正規分布形をとらないものがある がこれらの曲線についても一様に統計学的解析定行なつ た。

ガラス面などの反射における光度分布についてのこの
第 15 巻 第 2 号

ような統計学的解析は I. Nimeroff ${ }^{2}$, A. Dinsdale 子 F. Malkin ${ }^{3)}$ ，長谷川と川久保 ${ }^{4,5)}$ によ行なわれてい る.

表に示す值は光軸觉中心に $\pm 45^{\circ}$ の範囲で $5^{\circ}$ 間隔に ついて計算したものである. I. Nimeroff の計算例にし たがえば，測定点が 19 個であるので， $\sigma$ と $\alpha_{4}$ の範车活 つぎのようになる。

$$
\begin{aligned}
& 5.5 \geqq \sigma \geqq 0 \\
& 1.8 \leqq \alpha_{4} \leqq \infty, \text { したがつて } 0.56 \geqq 1 / \alpha_{4} \geqq 0
\end{aligned}
$$

理想的な完全拡散の場合, 直角座標表示で法光度一定 の，横軸に平行な線となるが，その場合

$$
\sigma=5.5, \quad 1 / \alpha_{4}=0.56 .
$$

非㕬散の場合, 直角座標表示では横軸の光軸位置飞垂 直に立つ直線となり，

$$
\sigma=0, \quad 1 / \alpha_{4}=0
$$

したがつて，型板ガラスの透過光度分布曲線てついて 得られた統計值, 標準偏差と, とがりの逆数の大きさか ら拡散の大きさを数值で示すことができる。

Fig. 6 には供試ガラスの分布曲線から得られた $\sigma$ と $1 / \alpha_{4}$ の関係をプロットして示した。各試料について得ら

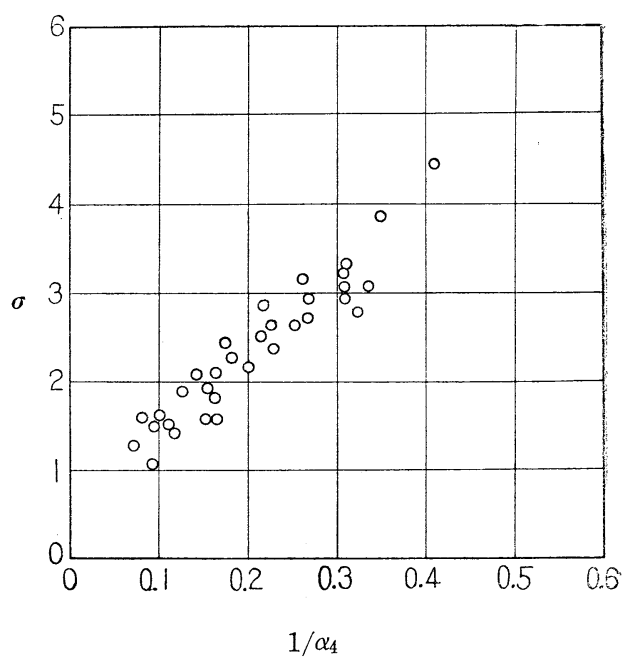

Fig. 6. Relation between dispersion indices and kurtosis indices obtained from goniometrical curves.

2) I. Nimeroff: J. Research of N.B.S. 48, 44I (1952).

3) A. Dinsdale and F. Malkin: Trans. Brit. Ceram. Soc. 54, 94 (1955).

4）長谷川泰, 川久保正一郎: 分光研究 7, 16 (1959).

5）長谷川泰, 川久保正一郎：分光研究 11, 245(1963)。 
Table 1. Statistical indices of goniometrical curves

\begin{tabular}{|c|c|c|c|c|c|c|}
\hline \multicolumn{2}{|r|}{ Sample } & \multirow{2}{*}{$\begin{array}{l}\text { Thick- } \\
\text { ness** }\end{array}$} & \multicolumn{2}{|c|}{ Index $* * *$} & \multirow{2}{*}{ Grade } & \multirow{2}{*}{ Ref. } \\
\hline No. & Designation* & & $\sigma$ & $1 / \alpha_{4}$ & & \\
\hline 1 & Nashiji & $\mathrm{S}$ & 2.93 & 0.268 & $\mathrm{~A}$ & Fig. $\quad 2-1$ \\
\hline 2 & Hatsushimo & $\mathrm{D}$ & 1.95 & 0.197 & $\mathrm{~B}$ & \\
\hline 3 & Daiya & $\mathrm{S}$ & 2.72 & 0.320 & $\mathrm{~A}$ & \\
\hline 4 & Teori & $\mathrm{S}$ & 3.12 & 0.257 & $\mathrm{~A}$ & Fig. 2-2 \\
\hline \multirow[t]{2}{*}{5} & Mōru Ral (V)* & $\mathrm{S}$ & 1.45 & 0.108 & $\mathrm{C}$ & Fig. $\quad 4-1$ \\
\hline & $(\mathrm{H})^{*}$ & & 1.32 & 0.067 & $\mathrm{C}$ & \\
\hline \multirow[t]{2}{*}{6} & Soft Mōru (V)* & $\mathrm{D}$ & 1.58 & 0.166 & $\mathrm{C}$ & Fig. $\quad 4-2$ \\
\hline & $(\mathrm{H})^{*}$ & & 1.69 & 0.074 & $\mathrm{C}$ & \\
\hline 7 & Shikishi & S & 2.32 & 0.231 & $\mathrm{~B}$ & \\
\hline 8 & Shigeri & $\mathrm{S}$ & 2.78 & 0.217 & A & Fig. $\quad 2-3$ \\
\hline 9 & Soft Ral & $\mathrm{S}$ & 2.74 & 0.265 & $\mathrm{~A}$ & Fig. $\quad 2-4$ \\
\hline 10 & Kasuri & $\mathrm{S}$ & 2.48 & 0.214 & $\mathrm{~B}$ & Fig. $\quad 3-1$ \\
\hline 11 & Ishigaki & $\mathrm{D}$ & 2.25 & 0.177 & B & Fig. $\quad 3-2$ \\
\hline 12 & Shikishi & $\mathrm{D}$ & 1.66 & 0.154 & $\mathrm{C}$ & \\
\hline 13 & Soft Ral & $\mathrm{D}$ & 2.53 & 0.223 & $\mathrm{~B}$ & \\
\hline 14 & Konoha & $\mathrm{S}$ & 2.07 & 0.166 & $\mathrm{~B}$ & Fig. $\quad 3-3$ \\
\hline 15 & Shin Shikishi & $\mathrm{S}$ & 2.16 & 0.200 & $\mathrm{~B}$ & Fig. $\quad 3-4$ \\
\hline 16 & Kirara & $\mathrm{S}$ & 2.46 & 0.170 & $\mathrm{~B}$ & Fig. $\quad 3-5$ \\
\hline 17 & Karuta & $\mathrm{D}$ & 1.67 & 0.091 & $\mathrm{C}$ & Fig. $\quad 5-1$ \\
\hline 18 & Rock Ral & $\mathrm{D}$ & 3.24 & 0.312 & A & Fig. $\quad 2-5$ \\
\hline \multirow[t]{2}{*}{19} & Pearl Mōru (V)* & $\mathrm{S}$ & 3.20 & 0.310 & A & \\
\hline & $(\mathrm{H})^{*}$ & & 1.93 & 0.158 & $\mathrm{C}$ & \\
\hline \multirow[t]{2}{*}{20} & 4-Bu Pearl Mōru (V)* & $\mathrm{D}$ & 2.83 & 0.316 & A & \\
\hline & $(\mathrm{H})^{*}$ & & 1.66 & 0.108 & $\mathrm{C}$ & \\
\hline \multirow[t]{2}{*}{21} & 8-Bu Pearl Mōru $(\mathrm{V})^{*}$ & $\mathrm{D}$ & 4. 34 & 0.415 & A & Fig. $4-3$ \\
\hline & $(\mathrm{H})^{*}$ & & 2.06 & 0.132 & $\mathrm{~B}$ & \\
\hline 22 & Rock Wire & D D & 2.98 & 0.332 & $\mathrm{~A}$ & \\
\hline 23 & Hatsushimo Wire & D D & 2. 63 & 0.251 & $\mathrm{~B}$ & Fig. $\quad 3-6$ \\
\hline 24 & Ground Glass & G S & 3.78 & 0.353 & A & Fig. $\quad 2-6$ \\
\hline 25 & Polished Glass & $\mathrm{P}$ & 1.01 & 0.092 & $\mathrm{C}$ & Fig. 5-2 \\
\hline
\end{tabular}

Foot note of Table 1.

* Sample No. 1-23: Japanese designation

(V): Ribbed pattern of figured glass is vertically set

(H): Ribbed pattern of figured glass is horizontally set

** S : $2 \mathrm{~mm}$; D : $4 \mathrm{~mm}$; DD: $7 \mathrm{~mm}$ (wired glass); GS: $1.9 \mathrm{~mm} ; \mathrm{P}: 6 \mathrm{~mm}$

*** Statistical index

$\sigma$ : Dispersion index; $1 / \alpha_{4} ;$ Kurtosis index 
れた $\sigma$ と $1 / \alpha_{4}$ の相関性は図からもかなりよいと見られ る.ここでは標準偏差の值の大小により拡散度を分類す ることにする。

完全拡散時の分布曲線における $\sigma$ の值を基準にとり, $\sigma=5.5(100 \%) ， 2.75(50 \%) ， 1.65(30 \%)$ を目安とし て拡散度它 $\mathrm{A}, \mathrm{B}, \mathrm{C} 3$ 段階に分けた.

$5.5 \geqq \sigma \geqq 2.75$ のときの拡散度を $\mathrm{A}$,

$2.75 \geqq \sigma \geqq 1.65$ のときの拡散度宏 $\mathrm{B}$,

$1.65 \geqq \sigma$ のときの拡散度を $\mathrm{C}$ とす。

この 3 段階で供試ガラス它拡散度合により分けると, A に属するもの:

No. $1,3,4,8,9,18,19(\mathrm{~V}), 20(\mathrm{~V}), 21(\mathrm{~V})$, 22,24

B に属するもの：

No. 2, 7, 10, 11, 13, 14, 15, 16, $19(\mathrm{H}), 21(\mathrm{H})$, 23

C に属するもの：

No. $5(\mathrm{~V}, \mathrm{H}), 6(\mathrm{~V}, \mathrm{H}), 12,17,20(\mathrm{H}), 25$

完全拡散基準にと礼将，拡散が半分以上のものが $11 ， 1 / 3$ 以下のものが 6 あり，中間が 11 あることにな る.百分率で示せば，最大が．No. 21 (V) で 79\%，最 底が No. 25 の $18 \%$ である。

\section{3 型模様と拡散度との関係}

供試型板ガラスの型模様を分類すると，まず小さな山 凸の集合，または直交線群による基本的な模様と，方向 性のあるリブ状の型模様があり，これに比較的大型な模 様をた汸方性のある模様に基本的な模様を組み合わせ た例が見られる。

方向性のない基本的な型模様の場合，いずれも拡散度 が大きい. 方向性のない研磨材粒子による微細な衝撃破 砕素面の集合である摺板（すりいた）ガラス面もこれに 入る.

大型の模様に基本的な小さな模様を組み合わせた型板 ガラスの透過光拡散度は, 厚多の小さい $(2 \mathrm{~mm})$ 場合, ほとえど組み合わせに関係なく大きいが，厚みの大きい (4 mm) 場合には組み合わせる小さな模様いかえにより 拡散度が大きく左右される傾向が見られる。同じ型模様 で厚みの相違による例它とれば No. 7 と No. 12 がこ れである. $\sigma_{\mathrm{No} .7}: 2.32, \sigma_{\mathrm{No} .12}: 1.66$.
また金網入り型板ガラス（厚み $7 \mathrm{~mm}$ ）の拡散度もか なりよい.同じ型模様で例安とれば

No. 2 厚み $4 \mathrm{~mm}, \sigma_{\text {No. } 2}: 1.95$

No. 23 厚文 $7 \mathrm{~mm}, \sigma_{\text {No. } 23}: 2.63$ (金網入り) ただし No. 18 と No. 22 のように型模様が同じ厚型板 と金網入りのように網入りでない方が拡散の大きい場合 もあるが，いずれも拡散度はAクラスに属する。

方向性のある模様も他の模様との組み合わせで搪散特 性が大いに異なること法 Fig. 4 から明らかである。こ のリブ状模様単独でも，リブ間隔が異なると拡散度も異 なる（No. 20 と 21）．方向により拡散度分犬たに異な ることは図より明らかで，例它 No. 21 亿とると (V) 方向と $(\mathrm{H})$ 方向では $\sigma_{(\mathrm{F})}: \sigma_{(\mathrm{H})}=4.34: 2.06 \fallingdotseq 2: 1$ で ある.このよう型板ガラスの取りつけ方向は使用目的 により注意する必要がある。

\section{4. 結論}

市販型板ガラスと磨板ガラス，摺板ガラスの垂直入射 光による透過光拡散の度合它対変角光度分布曲線形から 評価した結果をまとめるとつぎのようになる。

透過光の特性は型模様，厚みに影響を受け，例外壳除 いて, 供試型板ガラスの透過光拡散の度合恃磨板ガラス と摺板ガラスとの中間にある.

拡散度合の大きい型板ガラス注小さな凹凹模様または 線群模様単独か，さらにはこれに他の模樣を組み合わせ たものに多い。

同系の模様ならば，板厚の小さい方が拡散の大きい傾 向が認められた。

透過光拡散の度合注光軸方向の光度を基準にとると， 拡散度のよいもので, 約 $20^{\circ}$ の力向で光度が $1 / 2,30$ 〜 $40^{\circ}$ で $1 / 10$ になる。拡散度の小さい場合に核約 $10^{\circ}$ で 光軸方向の $1 / 10$ の光度になる.

方向性のある型模様で唀過光の光度分布にも方向性 が認められた。

本研究の実施にあたりセントラル硝子(株)研究所硝子 研究室の諸氏の協力学得た．また統計值の計算には日本 計算販売(株)の好意によるところが多い。併記し謝意を 表する. 